\title{
The role of the monoamine oxidase $A$ gene in moderating the response to adversity and associated antisocial behavior: a review
}

This article was published in the following Dove Press journal:

Psychology Research and Behavior Management

30 July 2014

Number of times this article has been viewed

\author{
Macià Buades-Rotger ${ }^{1,2}$ \\ David Gallardo-Pujol 1,3 \\ 'Department of Personality, Faculty of \\ Psychology, University of Barcelona, \\ Barcelona, Spain; '2Department of \\ Neurology, University of Lübeck, \\ Lübeck, Germany; 'Institute for Brain, \\ Cognition and Behavior (IR3C), \\ University of Barcelona, Barcelona, \\ Spain
}

\begin{abstract}
Hereditary factors are increasingly attracting the interest of behavioral scientists and practitioners. Our aim in the present article is to introduce some state-of-the-art topics in behavioral genetics, as well as selected findings in the field, in order to illustrate how genetic makeup can modulate the impact of environmental factors. We focus on the most-studied polymorphism to date for antisocial responses to adversity: the monoamine oxidase $A$ gene. Advances, caveats, and promises of current research are reviewed. We also discuss implications for the use of genetic information in applied settings.
\end{abstract}

Keywords: behavioral genetics, antisocial behaviors, monoamine oxidase A

\section{Introduction}

Our aim in the present paper is to provide an update of studies on the monoamine oxidase $A(M A O A)$ gene as a moderator of adversity-induced antisocial behavior (ASB). After a brief introduction of some key behavioral and molecular genetic concepts, we move on to review selected evidence on the $M A O A$-adversity-ASB triad; unlike previous reviews that focused only on correlational approaches, we also include experimental work that has shed light on the specific mechanisms underlying the aforementioned relationships. Moreover, we also discuss current and future issues in the applied use of genotyping.

\section{Genes moderate behavior}

Can genes moderate our daily behavioral responses? If so, how do genes moderate them? The moderation of behavior by genes, namely genetic sensitivity to environmental stimuli, is known as gene-environment $(\mathrm{G} \times \mathrm{E})$ interaction. More specifically, $\mathrm{G} \times \mathrm{E}$ interactions are said to occur when the effects of the environment on individuals vary by their genotype, or conversely, when environments modulate genetic effects. ${ }^{1}$ Behavioral $\mathrm{G} \times \mathrm{E}$ interaction studies thus operate according to the notion that individuals may have distinct genetic sensitivity to environmental conditions in the determination of a given outcome. Under this apparently simple reasoning, colliding views have been proposed regarding how $\mathrm{G} \times \mathrm{E}$ interactions take place. ${ }^{2}$ Does genetic makeup confer modified sensitivity to environmental stressors, or does it provide differential responsiveness to both favoring and detrimental environments? The former perspective corresponds to the diathesis-stress model, wherein genes are thought to determine individuals' vulnerability to environmental risk factors. The latter view matches the differential susceptibility model, which assumes that
Correspondence: David Gallardo-Pujo Institute for Brain, Cognition and Behavior (IR3C), University of Barcelona, Passeig de la Vall d'Hebron I7I, E-08035 Barcelona, Spain Email david.gallardo@ub.edu (c) (i) (8) ( 2014 Buades-Rotger and Gallardo-Pujol. This work is published by Dove Medical Press Limited, and licensed under Creative Commons Attribution - Non Commercia (unported, v3.0) License. The full terms of the License are available at http:///creativecommons.org/licenses/by-nc/3.0/. Non-commercial uses of the work are permitted Limited. Information on how to request permission may be found at: http://www.dovepress.com/permissions.php 
constitutional features shape general individual plasticity to environmental influences. ${ }^{2,3}$

While most $\mathrm{G} \times \mathrm{E}$ studies assume implicitly or explicitly the diathesis-stress model, ${ }^{2,3}$ some research has provided disagreeing evidence. For instance, van Ijzendoorn et $\mathrm{al}^{4}$ found support for the differential susceptibility model on the serotonin transporter gene's promoter region polymorphism (5HTTLPR) with a meta-analytic approach. Caucasian participants carrying the short allele - the risk variant - of the aforementioned polymorphism were more susceptible than individuals with the long allele to both positive environments $(r=0.21$ versus $r=0.11)$ and negative environments $(r=0.22$ versus $r=0.06$ ) for different behavioral, psychiatric, and developmental measures. These results support the assertion that certain assumedly risk-related genetic variants may help determining the degree to which individuals can benefit from favorable environmental conditions. ${ }^{5}$ In fact, carriers of risk alleles often have the lowest outcome scores in absence of environmental stressors and the highest scores when those stressors are present. ${ }^{2}$ As commented later on in this paper, the differential susceptibility hypothesis deserves further investigation.

Despite the appeal of the approaches briefly outlined above, it must be noted that they conceive of individuals as passive recipients of environmental influences, which are considered as external and independent from the person. In this sense, a line of research led by Robert Plomin caused an upheaval in our understanding of behavioral genetics when he treated the environment as a dependent variable, only to find that environmental measures could be partially determined by genetic variation. ${ }^{6}$

This led to the notion of gene-environment correlations $(\mathrm{rG} \times \mathrm{E})$, which emerge when genetic and environmental factors covary synergistically. ${ }^{7}$ Active $\mathrm{rG} \times \mathrm{E}$ occurs if individuals' genes drive the environments they select (nichepicking). Passive $\mathrm{rG} \times \mathrm{E}$ is said to happen when individuals receive genetic and environmental characteristics that reinforce mutually. Evocative $\mathrm{rG} \times \mathrm{E}$ takes place when individuals elicit responses in the environment in a way that matches their own inherited qualities. School achievement constitutes an excellent example to illustrate how $\mathrm{rG} \times \mathrm{E}$ can be relevant. Youngsters with greater intellectual ability are more likely to attend class (active $\mathrm{rG} \times \mathrm{E}$ ), where they may be stimulated by an academic environment (passive $\mathrm{rG} \times \mathrm{E}$ ) in which they evoke intellect-enhancing behaviors from their teachers (eg, pedagogical attention) and peers (eg, amusing discussions or debates). Given the ubiquitous influence of $\mathrm{rG} \times \mathrm{E}$, it has become customary to control for
$\mathrm{rG} \times \mathrm{E}$ in interactional approaches, ${ }^{8-10}$ although this is not always accomplished properly.

Aiming to reunite the existing perspectives on $\mathrm{G} \times \mathrm{E}$ relationships, a new framework emerged under the name of gene-environment transactions, ${ }^{8}$ which paralleled the development of the person-environment transactions models in personality and social psychology. ${ }^{11}$ The neutrality of the term "transactions" is on purpose, to include both interactional and correlational approaches to $\mathrm{G} \times \mathrm{E}$ relationships. This seems to be the next direction in behavioral genetics to fully account for the boundaries, direction, and magnitude of gene-to-environment and environment-to-gene effects. In this section, we have reviewed how genes and environment relate to each other, either interacting or correlating in a number of ways.

\section{Specific genes involved in behavioral responses}

In the previous section, we reviewed theoretical and empirical relationships between genes, environment, and behavior. But, how does this translate into specific findings? Some polymorphisms have been associated to psychological outcomes, ranging from basic processes (eg, working memory capacity, ${ }^{12}$ emotion perception $\left.{ }^{13}\right)$ to complex social behaviors (eg, altruism ${ }^{14}$ ); as time goes by, the number of such polymorphisms increases. In this sense, some genes have received more attention than others, depending on the existing preliminary evidence (eg, animal models) and theory on the role of certain genes (eg, putative implication in response to pathogen) when selecting candidate polymorphisms. ${ }^{1}$

The most extensively studied $\mathrm{G} \times$ E relationships to date are 5HTTLPR and stressful life events in depression, ${ }^{15}$ and the MAOA gene and childhood maltreatment in antisocial behavior. ${ }^{16}$ Genes related to dopaminergic activity, such as the catechol-O-methyl transferase (COMT) gene, ${ }^{17}$ the dopamine transporter gene, ${ }^{18}$ or polymorphisms encoding for distinct dopamine receptors (eg, DRD4) ${ }^{19}$ have also been widely examined. Whereas infantile conduct disorders ${ }^{19}$ and addictions ${ }^{20}$ are prominent outcomes in such studies, perhaps the most renowned $\mathrm{G} \times \mathrm{E}$ association involving dopamine systems is the effect of adolescent cannabis consumption in psychosis, varying upon COMTVal158/108Met genotype. ${ }^{21}$

One cautionary note must be stated here. Most of the research presented so far is based on association studies ${ }^{1}$ involving a single gene in conjunction with environmental measures; therefore, findings thus far have to be confirmed either via meta-analyses or complementary approaches that 
include causal exploration and more-complex models, such as gene-gene interactions, neuroimaging genetics, or experimental $\mathrm{G} \times \mathrm{E}$ research.

Hence, some genes can interact with other genes at different loci in a process called epistasis, or gene-gene interaction. ${ }^{8}$ The extent to which epistatic phenomena are relevant is still unclear, but their underlying logic is straightforward: because most complex traits have polygenic influences, might one gene buffer or enhance the effect of another? Epistatic interactions have been described in $\operatorname{mood}^{22}$ and behavior ${ }^{23}$ disorders, heralding a thrilling area of inquiry.

Once associations have been established between genes, environment, and behavior, a more-complete understanding of these relationships can be achieved by measuring genes' functional and biochemical correlates at a lower level of abstraction than the behavioral phenotype of interest. ${ }^{24}$ The rationale behind this strategy is that outcomes intermediate to behavior should be influenced by a lesser number of genes with more-distinguishable effects. ${ }^{24}$ For example, the COMT gene should have stronger effects on speed of performance than on general intelligence scores; in turn, concentration of the COMT enzyme in the frontal cortex should depend more on the COMT gene than on speed of performance. ${ }^{25}$

Functional neuroimaging and other in vivo techniques can lead to the characterization of these intermediate phenotypes, which Gottesman and Gould labeled "endophenotypes."26 They restricted the concept to heritable, state-independent, outcome-related, and co-segregated features. ${ }^{26}$ In the case mentioned above, one could test frontal levels of COMT as an endophenotype for intelligence. ${ }^{25}$ Although the concept of endophenotype is not universally accepted, confirming previously hypothesized - or unexpected - biochemical, neuropsychological, or cognitive pathways for gene action gives $\mathrm{G} \times$ E relationship findings a sounder ground. ${ }^{9,27}$

In addition, we can experimentally study the moderation of behavioral responses by the genotype in order to confirm the causal role of genes or the potential roles of expected moderators and to consequently bring these phenomena into the lab. In this sense, van Ijzendoorn and Bakermans$\mathrm{Kranenburg}^{28}$ review different alternatives to study $\mathrm{G} \times \mathrm{E}$ interactions experimentally and they provide some specific examples, from the serotonin transporter gene $(5-H T T)$ to the DRD4 gene. Although they do not mention any study involving the $M A O A$ gene, they do provide some examples on substance abuse, which is closely related to ASB.

In the following, we will attempt to provide an update of studies on the MAOA gene as a moderator of adversityinduced ASB. Unlike previous reviews that focused only on correlational approaches, we also include experimental work that has shed light on the specific causal pathways through which genetic effects are exerted and discuss applied genotyping in behavioral settings.

\section{The MAOA gene and its role in antisocial behavior}

The $M A O A$ gene was one of the first genes linked to antisocial behavior. Back in 1993, Brunner et $\mathrm{al}^{29}$ detected a rare mutation of the $M A O A$ gene in three generations of a Dutch family. This mutation hinders the synthesis of MAOA enzyme, which is responsible for degrading neurotransmitters such as serotonin or dopamine. All males carrying this structural anomaly had borderline intelligence and consistently displayed severe antisocial conducts such as arson and rape attempts, whereas females remained unaffected. (Brunner's finding must not be confused with another recently identified mutation in the $M A O A$ gene associated with a similar phenotype ${ }^{30}$ ). Located at the short arm of the X chromosome (position 11.23-11.4), the $M A O A$ gene has ever since been central in genetic studies of antisocial behavior.

Given that the mutation described by Brunner et $\mathrm{al}^{29}$ was highly uncommon, researchers inquired whether normal variations of the $M A O A$ gene could be relevant for ASB. Sabol et $\mathrm{al}^{31}$ found a polymorphic area in which a nucleotide sequence can be repeated $2,3,3.5,4$, or 5 times - although the authors did not report the 2-repeat variant in their original paper. Differences in sequence repeats are called "variable number of tandem repeats" (VNTR) and are generally associated to differential rates of transcription. In the case of the $M A O A$ gene, the 3.5-repeat and 4-repeat alleles had a markedly higher transcriptional efficiency (ie, led to an increased production of the MAOA enzyme) than did the 3-repeat and 5-repeat alleles. Hence, individuals are usually classified as possessing high-efficiency (3.5-repeat or 4-repeat) or low-efficiency (2-repeat, 3-repeat, or 5-repeat) alleles for this gene. It must be noted that the $M A O A$ gene is located at the X chromosome, and hence males are homozygous (ie, have only one copy of the allele). Females have two copies, and it is unclear how the expression of the $M A O A$ gene is affected by the natural random inactivation of one of the $\mathrm{X}$ chromosomes.

Caspi et $\mathrm{al}^{16}$ provided the first evidence that common variants of the $M A O A$ gene could modulate individuals' antisocial tendencies in interaction with childhood maltreatment in a longitudinal cohort comprehensively - the Dunedin study. Specifically, severely maltreated participants carrying the low-activity allele of the $M A O A$ gene displayed the 
highest scores in disposition toward violence and antisocial personality disorder scores, and demonstrated the greatest proportions of adolescent conduct disorder and convictions due to violent behavior.

Since Caspi et $\mathrm{al}^{16}$ published their milestone article, many studies have been conducted attempting to replicate and expand their findings to other domains of ASB. Given that Taylor and Kim-Cohen ${ }^{32}$ provided the last meta-analysis on the topic, we sought to review papers published in 2007 through 2013 tapping the $M A O A$ gene-adversity-ASB triad. We conducted searches on PubMed and Web of Science, selecting only empirical (not theoretical) articles conducted on human subjects using at least one environmental measure of adversity. References were hand-searched for possible nonretrieved articles. Figure 1 depicts the search sequence; Table 1 shows the search syntax used for each source.

The studies reviewed are presented in Tables 2 and 3. A majority of the studies included in this review present statistically significant evidence for the interaction between the $M A O A$ gene and environmental adversity measures (31 of 37). Overall, the pattern of results suggests that carriers of the low-activity variant of the $M A O A$ gene are more likely to incur ASB when reared in adverse environments. ${ }^{5,13,23,33-43}$ This pattern holds across

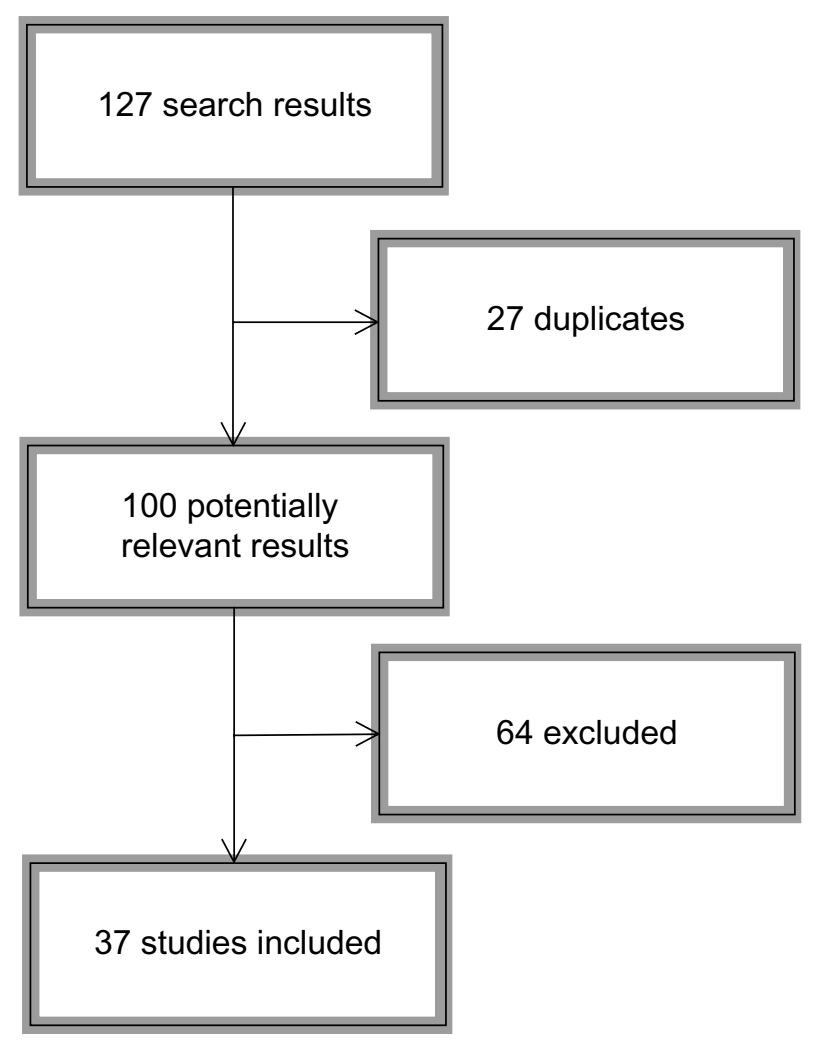

Figure I Flowchart depicting the bibliographic search process.
Table I Search syntax to locate articles conducted on human subjects with at least one environmental measure of adversity

\begin{tabular}{ll}
\hline PubMed & $((($ maoa[Title/Abstract]) OR (monoamine oxidase \\
& a[Title/Abstract])) AND (antisocial[Title/Abstract] OR \\
& agress*[Title/Abstract] OR viol*[Title/Abstract]) AND \\
& (advers*[Title/Abstract] OR abus*[Title/Abstract] \\
& OR maltreat*[Title/Abstract]))) AND (“2007”[Date - \\
& Publication]:“20I3”[Date - Publication]) \\
Web of Science & TOPIC: (MAOA OR monoamine oxidase a) \\
& AND TOPIC: (antisocial OR agress* OR viol*) \\
& AND TOPIC: (advers* OR abus* OR maltreat*). \\
& Timespan=2007-20I3. Search language=English. \\
&
\end{tabular}

disparate outcomes such as delinquency, aggressive dispositions, or attention deficit hyperactivity disorder. Among the several environmental stressors that are labeled as adversity, such as neglect, sexual abuse, or family dysfunction, childhood maltreatment shows the strongest effects in predicting ASB. There is thus remarkable variability across studies regarding measurement, sampling, and analytical procedures. Even if this complicates comparison between studies, it also increases confidence in the robustness of the MAOA-by-adversity interaction for ASB, as it has been found in a considerable range of samples assessed in a number of ways.

Extrafamilial social environment appears to be a powerful moderator of the $M A O A$-adversity interaction. Material deprivation, ${ }^{42}$ neighborhood disadvantage, ${ }^{5,44,45}$ and adoption of the "street code"43 all seem to add up to the effect of maltreatment, with low-activity allele carriers being at slightly greater risk for ASB in such rearing environments. Indeed, maltreatment is more likely to occur in an unfavorable broad social environment, which in turn offers fewer resources to overcome its pernicious consequences. ${ }^{45}$

Consistent with the rationale above, $\mathrm{G} \times \mathrm{E}$ effects for convictions are not as strong as for milder indices of ASB., ${ }^{5,38,42}$ This suggests that the types of ASB that lead to imprisonment may be more strongly influenced by macrosocial variables than solely by individual or familial features. However, failures to confirm this $\mathrm{G} \times \mathrm{E}$ interaction have also been reported. ${ }^{46,47}$ Perhaps the most outstanding among such findings are the results obtained by Haberstick et $\mathrm{al},{ }^{48}$ who placed formidable effort into replicating the original study by Caspi et al ${ }^{16}$ and did not find any interactive effect in a large sample.

Other studies have found $\mathrm{G} \times \mathrm{E}$ interactions with discordant results, associating the high-activity variant with greater ASB scores in the presence of early adversity; ${ }^{49-53}$ the reasons for these results are unclear. Even more intriguing, this trend is usual in female samples or subsamples. . $^{13,39,54-57}$ 


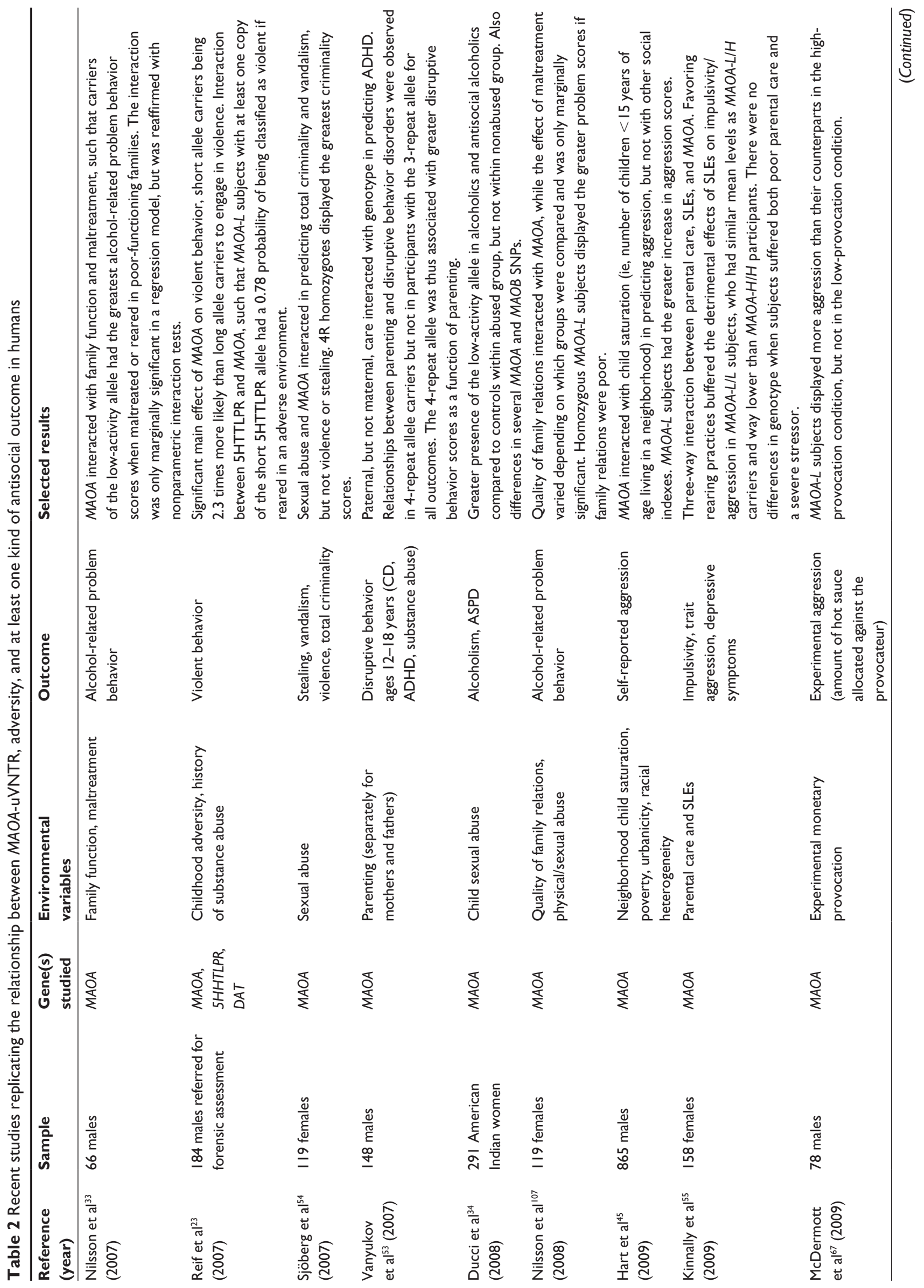




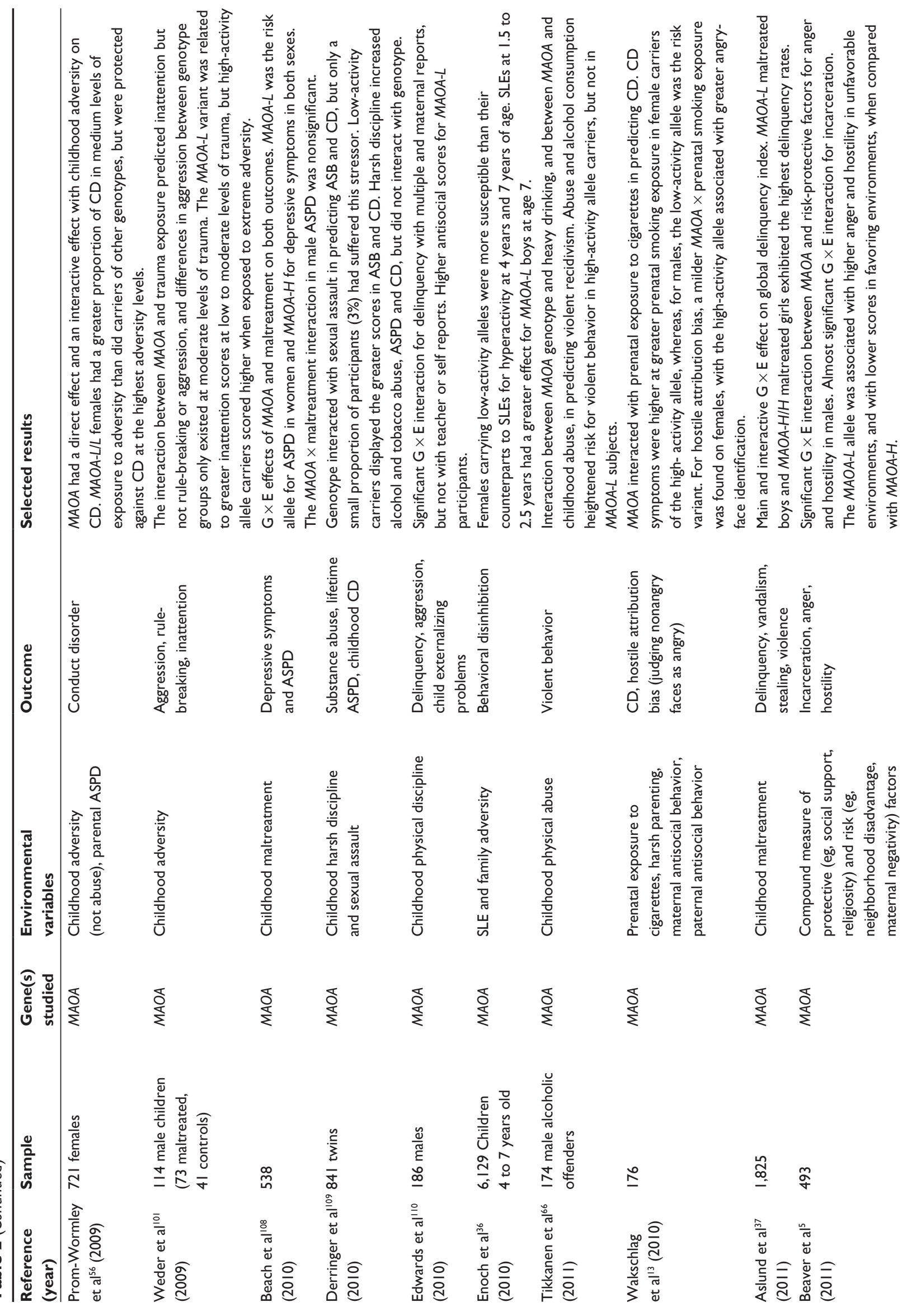



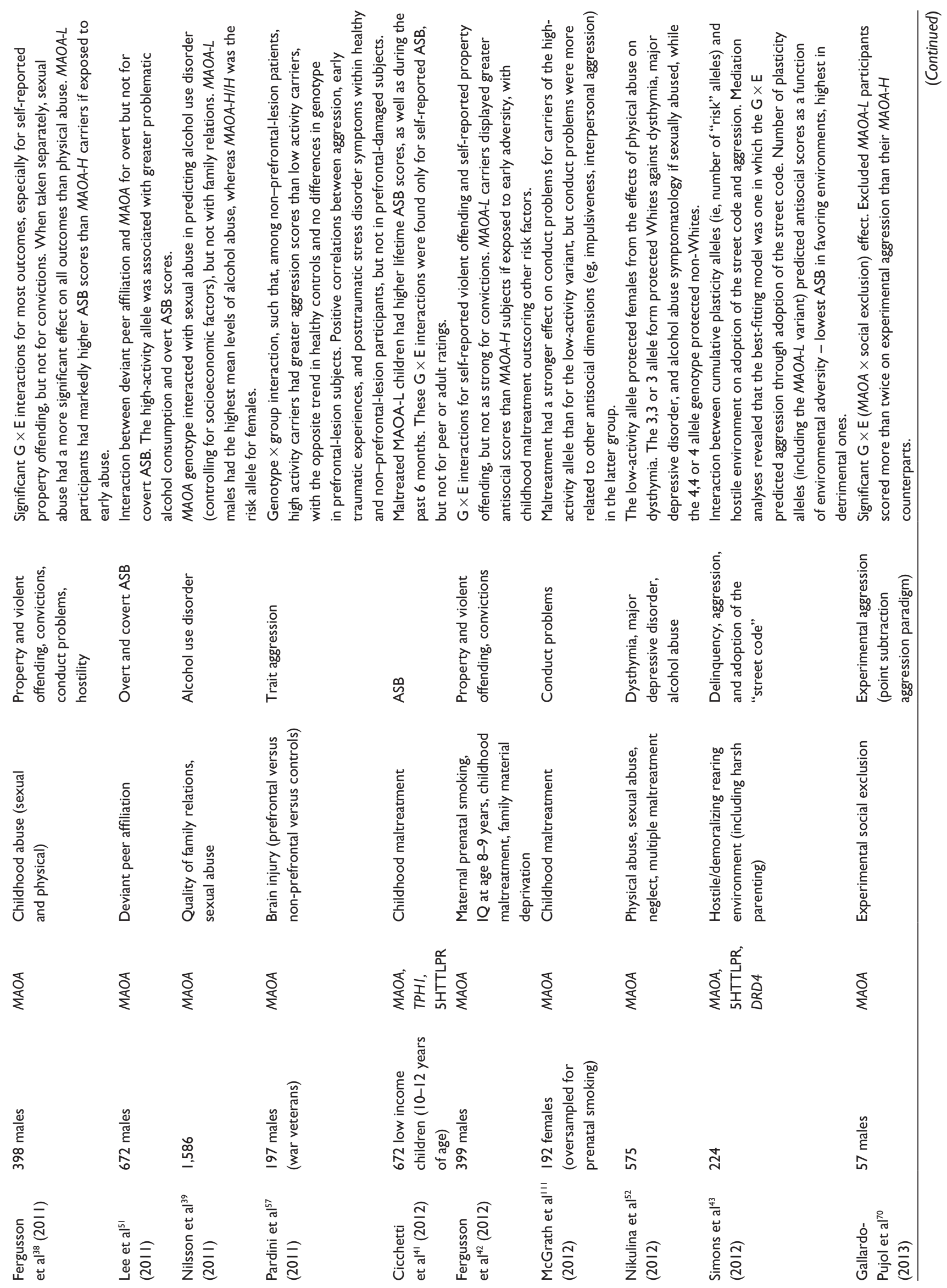
The latter results may be reflective of a gene-by-sex interaction, such that the low activity $(M A O A-L)$ variant would be the predominant risk or plasticity variant in males, whereas the high activity $(M A O A-H)$ variant would act as such in females. Unfortunately, the answer will remain subject to speculation until we have a clearer picture of the $M A O A$ gene's action in females. One of the main sources of general discrepancy across studies is the aforementioned methodological variability; the use of longitudinal versus cross-sectional approaches or the selection of instruments may influence results dramatically, let alone the ubiquitous measurement and sampling error. ${ }^{58}$ Furthermore, other artifacts such as population stratification (ie, differences in allelic frequencies between subpopulations) might have also biased some results in multiethnic samples. ${ }^{47,48}$ Such bias could be supported by reports from Lea and Chambers, ${ }^{59}$ who stirred controversy claiming that the increased percentage of 3-repeat alleles in a Maori population could represent a positive selection for behavioral aggression. However, their claims are not related to modern violence and are hardly generalizable to other populations, but they could explain a certain degree of population stratification. In fact, different allelic frequencies and variants could certainly alter the association between a gene and a complex genotype, which is the case of the oxytocin receptor gene ${ }^{60}$ and the serotonin transporter gene. ${ }^{61}$

Among noninteractive effects of the $M A O A$ gene, the 2 repeat (2R) allele has been linked to enhanced delinquency, as well as to strikingly lower levels of transcriptional activity, in comparison to all other variants. ${ }^{62,63}$ Nonetheless, monogenic effects tend to yield relatively low effect sizes, and should not be considered separately from the environment in applied work.

$\mathrm{ASB}$, as well as aggression, shows an exaggeratedly sex-specific prevalence. In fact, being a male dramatically increases the risk of displaying ASB, and one of the reasons that has been pointed out as an important determinant of these differences is the homozygosity of males for the $M A O A$ gene.$^{64}$ Females' heterozygosis may help to compensate the detrimental effects of the $M A O A-L$ allele through developmental deactivation of the $\mathrm{X}$ chromosome that carries the low-activity allele. There is some evidence suggesting that the $M A O A-H$ allele puts females in greater risk for overt ASB.$^{51}$ In any case, females have been shown to predominantly manifest ASB in subtler ways than males (eg, verbal rather than physical aggression). ${ }^{65}$ Relational, nonphysical aggression is a field of research that should yield relevant results in the future. Interestingly, the few studies that have 
Table 3 Recent studies failing to confirm the relationship between MAOA-uVNTR, adversity, and at least one kind of antisocial outcome in humans

\begin{tabular}{|c|c|c|c|c|c|}
\hline $\begin{array}{l}\text { Reference } \\
\text { (year) }\end{array}$ & Sample & $\begin{array}{l}\text { Gene(s) } \\
\text { studied }\end{array}$ & $\begin{array}{l}\text { Environmental } \\
\text { variables }\end{array}$ & Outcome & Selected results \\
\hline $\begin{array}{l}\text { Prichard et } \mathrm{al}^{49} \\
(2008)\end{array}$ & I,002 males & $M A O A$ & $\begin{array}{l}\text { General childhood } \\
\text { adversity } \\
\text { (including abuse) }\end{array}$ & Indicators of ASB & $\begin{array}{l}\text { MAOA } \times \text { adversity interaction only when } \\
\text { comparing participants who suffered }<2 \text { adversity } \\
\text { exposures with those who experienced } \\
2-5 \text { exposures. Carriers of the high activity allele } \\
\text { showed the highest ASB scores. }\end{array}$ \\
\hline $\begin{array}{l}\text { Van der Vegt } \\
\text { et } \mathrm{al}^{50}(2009)\end{array}$ & $\begin{array}{l}239 \text { adopted } \\
\text { boys }\end{array}$ & MAOA & $\begin{array}{l}\text { Childhood } \\
\text { maltreatment }\end{array}$ & $\begin{array}{l}\text { Externalizing behavior } \\
\text { (including aggressive } \\
\text { and delinquent behavior) }\end{array}$ & $\begin{array}{l}\text { The interaction between } M A O A \text { and maltreatment } \\
\text { almost reached significance for delinquency, } \\
\text { but not for aggression or the overarching } \\
\text { externalizing scale. Main effect for MAOA in all } \\
\text { measures, so that carriers of the high-activity } \\
\text { allele obtained higher scores than MAOA-L } \\
\text { participants. }\end{array}$ \\
\hline $\begin{array}{l}\text { Williams et al }{ }^{1 / 2} \\
(2009)\end{array}$ & 210 & MAOA & Early life stress & $\begin{array}{l}\text { Electroencephalographic } \\
\text { activity in a face- } \\
\text { processing task }\end{array}$ & $\begin{array}{l}\text { No interaction between number of early } \\
\text { stressful events and genotype in any brain region. } \\
\text { Interaction between genotype and sex in the } \\
\text { processing of emotional-valenced faces. MAOA-L } \\
\text { males had clearly reduced responses in several } \\
\text { parietal, frontal, and occipital brain areas when } \\
\text { presented with angry faces, whereas for females, } \\
\text { genotype differences existed only in the superior } \\
\text { occipital gyrus, and with an opposite pattern. }\end{array}$ \\
\hline $\begin{array}{l}\text { Verhoeven } \\
\text { et } \mathrm{al}^{46}(2012)\end{array}$ & 432 & $M A O A$ & $\begin{array}{l}\text { Childhood } \\
\text { adversity }\end{array}$ & $\begin{array}{l}\text { Anger, depression } \\
\text { sensitivity }\end{array}$ & $\begin{array}{l}\text { MAOA had a dose-dependent effect on the } \\
\text { aggression reactivity facet of depression sensitivity } \\
\text { in women, such that MAOA-H/H females scored } \\
\text { higher than MAOA-H/L ones, who, in turn, had } \\
\text { greater scores than } M A O A-L / L \text {. No genotype } \\
\text { effects were found on trait or state anger. } \\
\text { Childhood adversity did not interact with MAOA } \\
\text { genotype for any antisocial outcome. }\end{array}$ \\
\hline $\begin{array}{l}\text { Haberstick } \\
\text { et al }{ }^{48}(2014)\end{array}$ & 4,316 males & MAOA & $\begin{array}{l}\text { Childhood } \\
\text { maltreatment }\end{array}$ & $\begin{array}{l}\text { Adolescent conduct } \\
\text { problems, adult antisocial } \\
\text { behavior, convictions for } \\
\text { violent crimes, disposition } \\
\text { toward violence }\end{array}$ & $\begin{array}{l}\text { Significant though mild main effect of } M A O A \\
\text { gene on convictions for the whole sample, and } \\
\text { on disposition toward violence in White males. } \\
\text { Neither main nor interactive effects in any other } \\
\text { score. The absence of } \mathrm{G} \times \mathrm{E} \text { effects was not due } \\
\text { to lack of statistical power. }\end{array}$ \\
\hline $\begin{array}{l}\text { Sadeh } \\
\text { et }\left.a\right|^{47}(20 \mid 3)\end{array}$ & 237 males & $\begin{array}{l}\text { MAOA, } \\
\text { 5HTTLPR }\end{array}$ & $\begin{array}{l}\text { Childhood } \\
\text { maltreatment }\end{array}$ & Psychopathy & $\begin{array}{l}\text { Significant although small difference between } \\
M A O A-L \text { and MAOA-H subjects in the impulsive- } \\
\text { antisocial psychopathy dimension, higher for low- } \\
\text { activity carriers. No interaction of the MAOA gene } \\
\text { with childhood maltreatment. MAOA } \times 5 H T T L P R \\
\text { interaction was not tested, but } 5 H T T L P R \\
\text { showed effects on the affective and interpersonal } \\
\text { psychopathy dimensions. }\end{array}$ \\
\hline
\end{tabular}

Notes: Studies included here were published in 2007 or later, when the last meta-analysis on the topic was published by Taylor and Kim-Cohen ${ }^{32}$ (2007), except if not listed in such article. Articles are presented chronologically; the order is alphabetical for papers published the same year. Samples include participants of both sexes unless otherwise specified.

Abbreviations: $5 H T T L P R$, serotonin transporter linked polymorphic region; $A S B$, antisocial behavior; $G \times E$, gene-environment interaction; MAOA, monoamine oxidase $A$; MAOA-H, monoamine oxidase $A$ high-activity allele; MAOA-L, monoamine oxidase $A$ low-activity allele; uVNTR, upstream variable number of tandem repeats.

examined the role of $M A O A$ in psychopathy - characterized by instrumental aggressive tendencies - have yielded small or nonexistent effects, thus reinforcing the implication of this gene in reactive, rather than proactive, aggression. ${ }^{47,66}$

So far we have presented correlational research in which outcomes are often aggregated or self-reported measures. ${ }^{1}$
As in the case of other genes, as mentioned previously, some authors have brought this question into the lab and have shown that the $M A O A$ gene also moderates specific, pinpointed behaviors. In this sense, McDermott et al ${ }^{67}$ showed that after provocation, reactive aggression was higher among carriers of the low-activity allele of the $M A O A$ gene 
than among carriers of the high-activity allele, a recently replicated finding. ${ }^{68}$ Social exclusion has been usually put forward as a major source of provocation that leads to personal distress and eventually to aggression. ${ }^{69}$ In this sense, Gallardo-Pujol et al $^{70}$ experimentally replicated the finding from Caspi et $\mathrm{al}^{16}$ using an ad hoc procedure in which they combined behavioral genetics and social psychology. More specifically, they found that under conditions of social exclusion, $M A O A-L$ carriers were twice as likely to engage in aggressive behaviors than were $M A O A-H$ carriers. Another important contribution is that they provided guidelines for experimental research on $\mathrm{G} \times \mathrm{E}$ interactions. Interestingly, they suggest that experimental $\mathrm{G} \times \mathrm{E}$ research should follow these steps:

1) confirm that there is evidence of a given $G \times$ Einteraction from epidemiological genetic research; 2) search for analogs of environmental risk and target behavior; 3) search for independent effects of these analogs upon the dependent variable (behavioral task); 4) check the plausibility of the effect of the environmental analog on the biological systems involved in the task; 5) check the evidence of an association for the candidate gene with similar laboratory tasks; 6) control for any possible confounding variables (by blocking, covariates, etc); 7) test for $\mathrm{G} \times \mathrm{E}$ interaction; and finally 8 ) perform independent replication and meta-analysis. ${ }^{70}$

Once we have correlational and experimental evidence on the interaction of environmental adversity and the $M A O A$ gene, what is the next step? What do we know about the causal mechanisms from the gene to behavior and its interaction with environmental stimuli? Some clues may lie in the neural correlates of the $M A O A$ gene, as well as in brain areas responsive to adversity. If the cerebral circuitry associated to genetic variation couples with that observed in response to adversity, a clearer picture of the $M A O A$-adversity relationship may emerge. As commented next, this approach has yielded interesting results.

Eisenberger et $\mathrm{al}^{71}$ found that carriers of the low-activity $M A O A$ allele displayed greater activity in the anterior cingulate cortex as a response to experimentally induced social exclusion, as compared to $M A O A-H$ and $M A O A-H / L$ participants. This evidence suggested that carriers of the $M A O A-L$ variant would experience greater distress when confronted with adverse conditions.

Alia-Klein et $\mathrm{al}^{72}$ confirmed the functional relevance of the MAOA enzyme by showing moderate negative correlations of brain MAOA activity with trait aggression. However, no differences in enzymatic activity were found regarding genotype, in line with other research failing to find such relationship. ${ }^{73}$ These puzzling findings suggest that $M A O A$ genotype does not determine basal enzymatic action, in apparent contradiction with differences detected in structural and functional measures. ${ }^{74}$ Speculations converge in pointing out that $M A O A$ genotype may be especially crucial during early stages of development, ${ }^{72,73}$ such that the effects of genotype would only be relevant upon the action of a developmental or environmental disruption of this enzyme's activity. In line with this formulation, Huizinga et $\mathrm{al}^{75}$ found no $\mathrm{G} \times \mathrm{E}$ interaction when victimization was limited to adolescence.

Another study reported that $M A O A-L$ males displayed structural reductions in emotional processing areas (ie, bilateral amygdala and cingulate cortex) but increased functional activity in these same areas when evaluating angry versus fearful faces. ${ }^{74}$

Drawing upon this work, Buckholtz and MeyerLindenberg ${ }^{76}$ posited that the low-activity allele of the $M A O A$ gene conferred a more labile sociocognitive processing system, characterized by an increased tendency to respond hostilely to aggression cues - even if ambiguous. Biochemically speaking, these differences may translate into an excess of amygdaline reactivity that demands greater frontal regulatory action in $M A O A-L$ subjects; supporting this view, functional connectivity between ventromedial prefrontal cortex and amygdala has been associated with high levels of harm avoidance and angry hostility, ${ }^{77}$ as well as low reward dependence, in $M A O A-L$ (but not $M A O A-H$ ) males. ${ }^{76}$ By default, this pattern would only be manifest in the shape of temperamental variations within the normal range. Nevertheless, early disruptions in the serotonin and epinephrine circuits, such as those caused by maltreatment or other forms of environmental adversity, would render $M A O A-L$ participants more susceptible to reacting aggressively in social interactions. The serotonin deficiency hypothesis, which states that low serotonin levels would be associated with greater aggression, has been demonstrated to be an oversimplification, ${ }^{78}$ but it appears clear nonetheless that the $M A O A$ gene influences reactive aggression mainly through serotonergic imbalance. Note that the brain mechanisms mentioned above apply to structurally intact brains; however, a lesion study with war veterans has shown that an intact prefrontal cortex may be a prerequisite to detect genetic effects. ${ }^{57}$ See Table 2.

Taken together, these studies shed light about the causal mechanisms by means of which environmental adversity is moderated by the genotype, therefore providing intervention targets if they are needed. 


\section{Personalized genomics in the management of antisocial behavior}

In this section, we will focus on interventions for ASB, since it has been the most important outcome associated to the $M A O A$ gene, and how they could be improved by taking into account existing knowledge. Personalized genomics in this particular case could be fitted into the broader framework of neuroprediction. Neuroprediction is the use of biological data to predict future behavior. This term recently gained prominence in the realm of risk management after the publication of a longitudinal study in which the use of neuroimaging data successfully predicted rearrest. ${ }^{79,80}$ As we will see by the end of this section, taking genomics into account can significantly improve risk management. The incremental validity of including genomics in applied behavioral management remains to be tested, although this practice has been routinely incorporated into cancer protocols..$^{81}$ Genetic effects are often small, and therefore it is very unlikely that a single gene would yield a large increment in validity. Nonetheless, the more we know about multiple genes in relation to ASB and their interactions with other risk factors, the more prepared we will be to properly manage them.

Most interventions to prevent or treat ASB are based on single psychosocial risk factors. ${ }^{82}$ For instance, training in peer-group skills or mentoring programs are aimed at reducing the influence of deviant peers, a well-established risk factor. However, coming together with delinquent partners may well reflect active $\mathrm{rG} \times \mathrm{E}$, as youngsters might seek out such environments partially due to their own inherited tendencies. Hence, it is no surprise that success rates obtained by programs of this kind are inconsistent. ${ }^{82}$ Further quantitative genetics studies are required to draw clearer delineation between true criminogenic factors and those confounded with genetic influence. An accurate targeting of the factors to be modified could benefit not only society as a whole (eg, avoiding inefficient preventive policies), but also individuals (eg, by helping to adapt treatments for specific patients). ${ }^{83}$ Noteworthy, there is a growing interest in targeting specific risk factors as the most efficient way to cure a disorder, or as some authors suggest, "cause should inform cure". ${ }^{84,85}$

Following this line of reasoning, Collins,${ }^{86}$ among others, argued that diagnoses based on etiology rather than symptomatology should be more reliable and should allow for better-tailored environmental and behavioral treatments. This constitutes the core idea of what he called "personalized medicine". Hence, the identification of specific genetic variants probabilistically associated with certain outcomes directly taps into Collins' prophecy by allowing the assessment of constitutional risk and protective factors. In fact, this is socalled "therapygenetics", ${ }^{87}$ similar to pharmacogenetics.

The only study where the MAOA gene has been tested with therapeutic outcomes found that carriers of the highactivity allele had a worse response than low-activity carriers to cognitive-behavioral treatment for panic disorder with agoraphobia. ${ }^{88}$ More specifically, participants with the highactivity variant displayed less improvement than their counterparts in self-reported anxiety, avoidance (only in females who completed the whole study), and clinician-rated global severity. Furthermore, participants' responses in a behavioral avoidance test (BAT) revealed that subjects bearing the high activity allele had a faster heart rate in all BAT phases, benefitted less from repeated exposure, and reported more anxiety in anticipation and throughout the BAT than did low-activity allele carriers. This latter group also showed a neural activity pattern in a fear-conditioning paradigm suggestive of a better discrimination between anxiogenic stimuli. The implications of this study, pending replication, are manifold: carriers of the high-activity $M A O A$ variant may benefit more from treatments focused on autonomic arousal (eg, relaxation, betaadrenergic blockers) and might have an increased tendency to generalize learned fear responses, whereas individuals with the low-activity variants may have better response to usual cognitive-behavioral therapies, and thus might require less intensive pharmacological interventions. Similar studies with ASB as the main outcome would bring findings on the $M A O A$-adversity-ASB relationship into clinical practice, allowing the retest of epidemiological, correlational, and experimental evidence in a still-unexplored ambit.

Variations in the 5-HTT gene and in two DRD4 polymorphisms were tested in an early intervention program devised to improve mother-child attachment in maltreated and nonmaltreated 2 year olds. ${ }^{89}$ Whereas no genetic effects were found in maltreated children, there was a greater proportion of risk gene carriers among insecurely attached, nonmaltreated controls. This result is suggestive that the possible genetic influences in the development of motherchild relationships in normative populations may be diminished in presence of maltreatment. Considering the strong associations between maternal attachment and all kinds of psychopathology, it would be of great value to test the role of the MAOA gene in attachment processes, and especially in the response to preventive interventions. ${ }^{90}$

Overall, mapping patients' genotypes seems to be especially useful in the prediction of stimulus-contingent outcomes, but it may not translate well to the prediction of general dispositions. Genetic effects for broad personality 
dimensions were found to be inconsistent in an exhaustive meta-analysis, with effect sizes of specific polymorphisms on personality being predominantly small to moderate. ${ }^{91}$ However, as already commented, the $M A O A$ gene may predispose toward reactive aggression after provocation; it is therefore interesting to consider $M A O A$ genotype as a predictive tool in forensic or penitentiary settings, where hostile interpersonal interactions are common and estimating the risk of recidivism is crucial. We further argue that inquiring about the past maltreatment history of inmates or indicted individuals, complemented with their genetic makeup, can give important clues when it comes to assessing the likelihood of future ASB arising from social interactions.

It is almost compulsory to cite, in this regard, the work by Bernet et al, ${ }^{92}$ who depicted a series of cases in which genetic information was presented as evidence in murder trials. The authors first reviewed precedent cases, in two of which they raised the possibility that conviction reductions could have been influenced by genotypic evidence. Subsequently, the authors related their own experience in the use of genotype in murder trials, where they exposed the extenuatory influence of either the MAOA or the 5-HTT risk allele in combination with past history of harsh discipline or maltreatment. It is noteworthy, however, that the authors selectively presented the genetic markers that most favored the defendants, obviating putative gene-gene interactive effects - only one case had the risk allele in both measured genes. Furthermore, they alleged a general predisposition toward violence conferred by genes instead of relating it to specific instances of the situation in which murder occurred. Nonetheless, genotypic evidence has also been presented in an Italian murder trial, in which the defense alleged genetic risk for aggressive reactions to provocation, without considering the defendant's upbringing; in this case, the indicted saw his conviction reduced..$^{93}$

At this point we want to draw attention to the fact that utilizing specific genes in trials is a relatively novel practice, but the allegation of "genetic predisposition" - usually on the basis of familial aggregation - is more established; Pioro et al have recently found this term in 468 different legal decisions when reviewing Canadian judicial databases. ${ }^{94}$ Farahany and Coleman ${ }^{95}$ encouraged caution regarding the use of genetic factors as evidence in court, considering that behavioral genetic evidence was still poorly suited to apprehend individual cases, and that the prevailing concepts on liability such as legal free will - drained a great deal of importance from genetic factors in law; see Baum ${ }^{96}$ for further discussion. Although we agree on the need for wariness until more- thorough studies come out, the recently observed effects of the $M A O A$ gene in experimental situations, ${ }^{67,70}$ obtained with very small samples and in controlled conditions, permit greater confidence in $\mathrm{G} \times \mathrm{E}$ interaction results at an individual level of analysis. Therefore, we suggest that the use of genotype in trials should be limited to cases of impulsive (rather than premeditated) crimes, with clearly demonstrable risk factors (eg, childhood severe adversity), and offering explicit and specific relationships between genetic makeup and the circumstances in which the offense occurred - such as provocation - that might have served as a trigger.

Finally, although internalizing psychopathology is not our present focus, we will introduce a brief note on the topic due to its relevance in forensic practice. In this ambit, it is worth mentioning a recent meta-analysis that has discarded the implication of the $M A O A$ gene on suicidal behavior. ${ }^{97}$ While the high activity variant of the $M A O A$ gene seems to protect males from ASB, it may heighten liability to anxiety and depression in females. ${ }^{52}$ This has led some researchers to label the $M A O A$ as the "warrior-worrier gene", ${ }^{88}$ but more evidence is needed to test the validity of this somewhat simplistic tag. It appears wise, in future research, to explore how the $M A O A$ gene may relate differently to the internalizing and externalizing spectra, or even with the recently derived general psychopathology factor, or $p .{ }^{98}$

\section{Conclusions and therapy implications}

Future $\mathrm{G} \times \mathrm{E}$ studies should place special effort in sampling not only adverse environments, but also beneficial ones. The fact that presumed risk alleles have been related to greater positive responses to protective factors ${ }^{5,99}$ questions several results presented here, as only adverse environmental factors are considered in the majority of $\mathrm{G} \times \mathrm{E}$ studies. Although great effort is expended to make samples representative of the different socioeconomic strata, a more-comprehensive assessment of identifiable positive factors would allow testing of whether some alleles are indeed simple risk variants, or if they map into greater behavioral variability in the presence of both detrimental and reinforcing environments.

Even if we only focus on the pathological side, multidimensional measures of environmental features can help uncover differential response patterns; Kinnaly et al, ${ }^{100}$ for instance, used a self-report of parental care and a separate questionnaire of stressful life events (eg, death of a close relative, physical or sexual abuse), and, as explained in Table 2, found different effects for each environmental variable. Indeed, studies that go beyond the usual two-level or 
three-level scale for adversity often find subtle effects that cannot be captured in dichotomic measures. ${ }^{49,56,101}$ These are just a few examples of how the impact of environmental variables can be diverse. This is of crucial importance for those theories of crime that focus only on environmental aspects, as disentangling the relative importance of each level of environmental factors can lead to more successful environmental interventions.

As we have seen so far, the $M A O A$ gene, in conjunction with environmental adversity, seems to play a central role in the genesis of ASB and related outcomes. Even though there is still some controversy, epidemiological, clinical, and experimental research converges in providing evidence for it.

All in all, the take-home messages about incorporating $\mathrm{G} \times \mathrm{E}$ research in applied settings are three. First, with respect to ASB management, incorporating genetic data into current risk assessment procedures, such as HCR-20 or Offender Group Reconviction Scale, ${ }^{102}$ could improve risk management protocols, especially in forensic settings. ${ }^{103,104}$ Second, taking genetic data into account could be useful in order to detect individuals at a greater risk of victimization, ${ }^{89}$ or at least, the most vulnerable ones. And last but not least, the use of genetic data could be useful to compare the performance of specific psychological treatments versus specific pharmacological treatments, as Lester and Eley suggested. ${ }^{105}$

Future research in this area should seek to fill the gaps in four main points. First, research testing the incremental validity of genomics testing in risk management settings must be conducted, especially using longitudinal designs. Neuroprediction ${ }^{79}$ has proven successful in spite of criticisms concerning the reliability of neuroimaging data. Genetic data is often considered more reliable, though their effects are smaller. Also, modeling their interactions with environmental risk factors should lead to better risk management. Second, research on factors predisposing to victimization has been considered taboo, as some nonacademic organizations consider this as blaming the victims. However, this type of research would help focus our interventions on them. In turn, this would lead to a rationalization in the allocation of resources. Actually, personality allows identification of those individuals that lack most resources to cope with severe forms of maltreatment, such as childhood sexual abuse, ${ }^{11}$ and we should not forget that personality traits are highly heritable. ${ }^{106}$ Third, little is known about why different genotypes confer differential sensitivities to psychological treatments, although some hypotheses have been suggested. These hypotheses are yet to be tested. Finally, as some other researchers have pointed out, understanding the $M A O A$-adversity-ASB triad can lead to unraveling the causal mechanisms and therefore allow more-successful interventions.

In conclusion, the moderating role of the $M A O A$ gene on the development of antisocial behavior is not only useful for basic research and advancing in the ethiological knowledge of ASB, but also for managing risk and interventions in applied clinical and forensic settings.

\section{Disclosure}

The authors report no conflicts of interest in this work.

\section{References}

1. Caspi A, Moffitt TE. Gene-environment interactions in psychiatry: joining forces with neuroscience. Nat Rev Neurosci. 2006;7(7):583-590.

2. Belsky J, Jonassaint C, Pluess M, Stanton M, Brummett B, Williams R. Vulnerability genes or plasticity genes? Mol Psychiatry. 2009;14(8): 746-754.

3. Belsky J, Pluess M. Beyond diathesis stress: differential susceptibility to environmental influences. Psychol Bull. 2009;135(6):885-908.

4. van Ijzendoorn MH, Belsky J, Bakermans-Kranenburg MJ. Serotonin transporter genotype 5HTTLPR as a marker of differential susceptibility? A meta-analysis of child and adolescent gene-by-environment studies. Transl Psychiatry. 2012;2:e147.

5. Beaver KM, Nedelec JL, Wilde M, Lippoff C, Jackson D. Examining the association between MAOA genotype and incarceration, anger and hostility: The moderating influences of risk and protective factors. J Res Pers. 2011;45(3):279-284.

6. Scarr S, Mccartney K. How people make their own environments: a theory of genotype greater than environment effects. Child Dev. 1983;54(2):424-435.

7. O'Connor TG, Deater-Deckard K, Fulker D, Rutter M, Plomin R. Genotype-environment correlations in late childhood and early adolescence: antisocial behavioral problems and coercive parenting. Dev Psychol. 1998;34(5):970-981.

8. Johnson W, Penke L, Spinath FM. Heritability in the era of molecular genetics: some thoughts for understanding genetic influences on behavioural traits. Eur J Pers. 2011;25(4):254-266.

9. Rutter M. Biological implications of gene-environment interaction. J Abnorm Child Psychol. 2008;36(7):969-975.

10. Plomin R, Bergeman CS. The nature of nurture: genetic influence on "environmental" measures. Behav Brain Sci. 1991;14(3):373-386.

11. Gallardo-PujolD, Pereda N. Person-environment transactions: personality traits moderate and mediate the effects of child sexual victimization on psychopathology. Personal Ment Health. 2013;7(2):102-113.

12. Ziermans T, Dumontheil I, Roggeman C, et al. Working memory brain activity and capacity link MAOA polymorphism to aggressive behavior during development. Transl Psychiatry. 2012;2:e85.

13. Wakschlag LS, Kistner EO, Pine DS, et al. Interaction of prenatal exposure to cigarettes and MAOA genotype in pathways to youth antisocial behavior. Mol Psychiatry. 2010;15(9):928-937.

14. Knafo A, Israel S, Ebstein RP. Heritability of children's prosocial behavior and differential susceptibility to parenting by variation in the dopamine receptor D4 gene. Dev Psychopathol. 2011;23(1):53-67.

15. Caspi A, Sugden K, Moffitt TE, et al. Influence of life stress on depression: moderation by a polymorphism in the 5-HTT gene. Science. 2003;301(5631):386-389.

16. Caspi A, McClay J, Moffitt TE, et al. Role of genotype in the cycle of violence in maltreated children. Science. 2002;297(5582):851-854.

17. Qian QJ, Liu J, Wang YF, Yang L, Guan LL, Faraone SV. Attention Deficit Hyperactivity Disorder comorbid oppositional defiant disorder and its predominately inattentive type: evidence for an association with COMT but not MAOA in a Chinese sample. Behav Brain Funct. 2009;5:8. 
18. Langley K, Turic D, Rice F, et al. Testing for gene $\mathrm{x}$ environment interaction effects in attention deficit hyperactivity disorder and associated antisocial behavior. Am J Med Genet B Neuropsychiatr Genet. 2008;147B(1):49-53.

19. Li D, Sham PC, Owen MJ, He L. Meta-analysis shows significant association between dopamine system genes and attention deficit hyperactivity disorder (ADHD). Hum Mol Genet. 2006;15(14): 2276-2284.

20. Gorwood P, Le Strat Y, Ramoz N, Dubertret C, Moalic JM, Simonneau M. Genetics of dopamine receptors and drug addiction. Hum Genet. 2012;131(6):803-822.

21. CaspiA, MoffittTE, Cannon M, et al. Moderation of the effect of adolescentonset cannabis use on adult psychosis by a functional polymorphism in the catechol-O-methyltransferase gene: longitudinal evidence of a gene $\mathrm{X}$ environment interaction. Biol Psychiatry. 2005;57(10):1117-1127.

22. Priess-Groben HA, Hyde JS. 5-HTTLPR X stress in adolescent depression: moderation by MAOA and gender. JAbnorm Child Psychol. 2013;41(2):281-294.

23. Reif A, Rösler M, Freitag CM, et al. Nature and nurture predispose to violent behavior: serotonergic genes and adverse childhood environment. Neuropsychopharmacology. 2007;32(11):2375-2383.

24. Martinez D, Broft A, Laruelle M. Imaging neurochemical endophenotypes: promises and pitfalls. Pharmacogenomics. 2001;2(3):223-237.

25. Barnett JH, Scoriels L, Munafò MR. Meta-analysis of the cognitive effects of the catechol-O-methyltransferase gene Val158/108Met polymorphism. Biol Psychiatry. 2008;64(2):137-144.

26. Gottesman II, GouldTD. The endophenotype concept in psychiatry: etymology and strategic intentions. Am J Psychiatry. 2003;160(4): 636-645.

27. Moffitt TE, Caspi A, Rutter M. Strategy for investigating interactions between measured genes and measured environments. Arch Gen Psychiatry. 2005;62(5):473-481.

28. Van Ijzendoorn MH, Bakermans-Kranenburg MJ. Differential susceptibility experiments: going beyond correlational evidence: comment on beyond mental health, differential susceptibility articles. Dev Psychol. 2012;48(3):769-774.

29. Brunner HG, Nelen M, Breakefield XO, Ropers HH, van Oost BA. Abnormal behavior associated with a point mutation in the structural gene for monoamine oxidase A. Science. 1993;262(5133):578-580.

30. Piton A, Poquet H, Redin C, et al. 20 ans après: a second mutation in MAOA identified by targeted high-throughput sequencing in a family with altered behavior and cognition. Eur J Hum Genet. 2014;22(6):776-783.

31. Sabol SZ, Hu S, Hamer D. A functional polymorphism in the monoamine oxidase A gene promoter. Hum Genet. 1998;103(3):273-279.

32. Taylor A, Kim-Cohen J. Meta-analysis of gene-environment interactions in developmental psychopathology. Dev Psychopathol. 2007;19(4): 1029-1037.

33. Nilsson KW, Sjöberg RL, Wargelius HL, Leppert J, Lindström L, Oreland L. The monoamine oxidase A (MAO-A) gene, family function and maltreatment as predictors of destructive behaviour during male adolescent alcohol consumption. Addiction. 2007;102(3):389-398.

34. Ducci F, Enoch MA, Hodgkinson C, et al. Interaction between a functional MAOA locus and childhood sexual abuse predicts alcoholism and antisocial personality disorder in adult women. Mol Psychiatry. 2008;13(3):334-347.

35. Sjöberg RL, Ducci F, Barr CS, et al. A non-additive interaction of a functional MAO-A VNTR and testosterone predicts antisocial behavior. Neuropsychopharmacology. 2008;33(2):425-430.

36. Enoch MA, Steer CD, Newman TK, Gibson N, Goldman D. Early life stress, MAOA, and gene-environment interactions predict behavioral disinhibition in children. Genes Brain Behav. 2010;9(1):65-74.

37. Aslund C, Nordquist N, Comasco E, Leppert J, Oreland L, Nilsson KW. Maltreatment, MAOA, and delinquency: sex differences in geneenvironment interaction in a large population-based cohort of adolescents. Behav Genet. 2011;41(2):262-272.

38. Fergusson DM, Boden JM, Horwood LJ, Miller AL, Kennedy MA. MAOA, abuse exposure and antisocial behaviour: 30-year longitudinal study. Br J Psychiatry. 2011;198(6):457-463.
39. Nilsson KW, Comasco E, Åslund C, Nordquist N, Leppert J, Oreland L. MAOA genotype, family relations and sexual abuse in relation to adolescent alcohol consumption. Addict Biol. 2011;16(2):347-355.

40. Reti IM, Xu JZ, Yanofski J, et al. Monoamine oxidase A regulates antisocial personality in whites with no history of physical abuse. Compr Psychiatry. 2011;52(2):188-194.

41. Cicchetti D, Rogosch FA, Thibodeau EL. The effects of child maltreatment on early signs of antisocial behavior: genetic moderation by tryptophan hydroxylase, serotonin transporter, and monoamine oxidase A genes. Dev Psychopathol. 2012;24(3):907-928.

42. Fergusson DM, Boden JM, Horwood LJ, Miller A, Kennedy MA. Moderating role of the MAOA genotype in antisocial behaviour. $\mathrm{Br} J$ Psychiatry. 2012;200(2):116-123.

43. Simons RL, Lei MK, Stewart EA, et al. Social adversity, genetic variation, street code, and aggression: a geneticlly informed model of violent behavior. Youth Violence Juv Justice. 2012;10(1):3-24.

44. Hill J, Breen G, Quinn J, Tibu F, Sharp H, Pickles A. Evidence for interplay between genes and maternal stress in utero: monoamine oxidase A polymorphism moderates effects of life events during pregnancy on infant negative emotionality at 5 weeks. Genes Brain Behav. 2013;12(4):388-396.

45. Hart D, Marmorstein NR. Neighborhoods and genes and everything in between: understanding adolescent aggression in social and biological contexts. Dev Psychopathol. 2009;21(3):961-973.

46. Verhoeven FE, Booij L, Kruijt AW, Cerit H, Antypa N, Does W. The effects of MAOA genotype, childhood trauma, and sex on trait and state-dependent aggression. Brain Behav. 2012;2(6):806-813.

47. Sadeh N, Javdani S, Verona E. Analysis of monoaminergic genes, childhood abuse, and dimensions of psychopathy. J Abnorm Psychol. 2013;122(1):167-179.

48. Haberstick BC, Lessem JM, Hewitt JK, et al. MAOA genotype, childhood maltreatment, and their interaction in the etiology of adult antisocial behaviors. Biol Psychiatry. 2014;75(1):25-30.

49. Prichard Z, Mackinnon A, Jorm AF, Easteal S. No evidence for interaction between MAOA and childhood adversity for antisocial behavior. Am J Med Genet B Neuropsychiatr Genet. 2008;147B(2):228-232.

50. Van derVegt EJ, Oostra BA, Arias-VásquezA, van der Ende J, Verhulst FC, Tiemeier H. High activity of monoamine oxidase A is associated with externalizing behaviour in maltreated and nonmaltreated adoptees. Psychiatr Genet. 2009;19(4):209-211.

51. Lee SS. Deviant peer affiliation and antisocial behavior: interaction with monoamine oxidase A (MAOA) genotype. J Abnorm Child Psychol. 2011;39(3):321-332.

52. Nikulina V, Widom CS, Brzustowicz LM. Child abuse and neglect, MAOA, and mental health outcomes: a prospective examination. Biol Psychiatry. 2012;71(4):350-357.

53. Vanyukov MM, Maher BS, Devlin B, et al. The MAOA promoter polymorphism, disruptive behavior disorders, and early onset substance use disorder: gene-environment interaction. Psychiatr Genet. 2007;17(6): 323-332.

54. Sjöberg RL, Nilsson KW, Wargelius HL, Leppert J, Lindström L, Oreland L. Adolescent girls and criminal activity: role of MAOA-LPR genotype and psychosocial factors. Am J Med Genet B Neuropsychiatr Genet. 2007;144B(2):159-164.

55. Kinnally EL, Huang YY, Haverly R, et al. Parental care moderates the influence of MAOA-uVNTR genotype and childhood stressors on trait impulsivity and aggression in adult women. Psychiatr Genet. 2009;19(3):126-133.

56. Prom-Wormley EC, Eaves LJ, Foley DL, et al. Monoamine oxidase A and childhood adversity as risk factors for conduct disorder in females. Psychol Med. 2009;39(4):579-590.

57. Pardini M, Krueger F, Hodgkinson C, et al. Prefrontal cortex lesions and MAO-A modulate aggression in penetrating traumatic brain injury. Neurology. 2011;76(12):1038-1045.

58. Monroe SM, Reid MW. Gene-environment interactions in depression research: genetic polymorphisms and life-stress polyprocedures. Psychol Sci. 2008;19(10):947-956. 
59. Lea R, Chambers G. Monoamine oxidase, addiction, and the "warrior" gene hypothesis. N Z Med J. 2007;120(1250):U2441.

60. Kim HS, Sherman DK, Mojaverian T, et al. Gene-culture interaction: oxytocin receptor polymorphism (OXTR) and emotion regulation. Soc Psychol Personal Sci. 2011;2(6):665-672.

61. Chiao JY, Blizinsky KD. Culture-gene coevolution of individualismcollectivism and the serotonin transporter gene. Proc Biol Sci. 2010; 277(1681):529-537.

62. Guo G, Ou XM, Roettger M, Shih JC. The VNTR 2 repeat in MAOA and delinquent behavior in adolescence and young adulthood: associations and MAOA promoter activity. Eur J Hum Genet. 2008;16(5):626-634.

63. Beaver KM, Wright JP, Boutwell BB, Barnes JC, Delisi M, Vaughn MG. Exploring the association between the 2-repeat allele of the MAOA gene promoter polymorphism and psychopathic personality traits, arrests, incarceration, and lifetime antisocial behavior. Pers Individ Dif. 2013;54(2):164-168.

64. Eme R. Male life-course-persistent antisocial behavior: the most important pediatric mental health problem. Arch Pediatr Adolesc Med. 2010;164(5):486-487.

65. Li JJ, Lee S. Latent class analysis of antisocial behavior: interaction of serotonin transporter genotype and maltreatment. J Abnorm Child Psychol. 2010;38(6):789-801.

66. Tikkanen R, Auvinen-Lintunen L, Ducci F, et al. Psychopathy, PCL-R, and MAOA genotype as predictors of violent reconvictions. Psychiatry Res. 2011;185(3):382-386.

67. McDermott R, Tingley D, Cowden J, Frazzetto G, Johnson DD. Monoamine oxidase A gene (MAOA) predicts behavioral aggression following provocation. Proc Natl Acad Sci U S A. 2009;106(7):2118-2123.

68. Kuepper Y, Grant P, Wielpuetz C, Hennig J. MAOA-uVNTR genotype predicts interindividual differences in experimental aggressiveness as a function of the degree of provocation. Behav Brain Res. 2013;247: 73-78.

69. Williams KD. Ostracism: The kiss of social death. Soc Personal Psychol Compass. 2007;1(1):236-247.

70. Gallardo-Pujol D, Andrés-Pueyo A, Maydeu-Olivares A. MAOA genotype, social exclusion and aggression: an experimental test of a geneenvironment interaction. Genes Brain Behav. 2013;12(1):140-145.

71. Eisenberger NI, Way BM, Taylor SE, Welch WT, Lieberman MD. Understanding genetic risk for aggression: clues from the brain's response to social exclusion. Biol Psychiatry. 2007;61(9):1100-1108.

72. Alia-Klein N, Goldstein RZ, Kriplani A, et al. Brain monoamine oxidase A activity predicts trait aggression. J Neurosci. 2008;28(19): 5099-5104.

73. Fowler JS, Alia-Klein N, Kriplani A, et al. Evidence that brain MAO A activity does not correspond to MAO A genotype in healthy male subjects. Biol Psychiatry. 2007;62(4):355-358.

74. Meyer-Lindenberg A, Buckholtz JW, Kolachana B, et al. Neural mechanisms of genetic risk for impulsivity and violence in humans. Proc Natl Acad Sci USA. 2006;103(16):6269-6274.

75. Huizinga D, Haberstick BC, Smolen A, et al. Childhood maltreatment, subsequent antisocial behavior, and the role of monoamine oxidase A genotype. Biol Psychiatry. 2006;60(7):677-683.

76. Buckholtz JW, Meyer-Lindenberg A. MAOA and the neurogenetic architecture of human aggression. Trends Neurosci. 2008;31(3):120-129.

77. Buckholtz JW, Callicott JH, Kolachana B, et al. Genetic variation in MAOA modulates ventromedial prefrontal circuitry mediating individual differences in human personality. Mol Psychiatry. 2008;13(3): 313-324.

78. Duke AA, Bègue L, Bell R, Eisenlohr-Moul T. Revisiting the serotonin-aggression relation in humans: a meta-analysis. Psychol Bull. 2013;139(5):1148-1172.

79. Aharoni E, Vincent GM, Harenski CL, et al. Neuroprediction of future rearrest. Proc Natl Acad Sci U S A. 2013;110(15):6223-6228.

80. Nadelhoffer T, Bibas S, Grafton S, et al. Neuroprediction, violence, and the law: setting the stage. Neuroethics. 2010;5(1):67-99.

81. Weitzel JN, Blazer KR, Macdonald DJ, Culver JO, Offit K. Genetics, genomics, and cancer risk assessment: state of the art and future directions in the era of personalized medicine. CA Cancer J Clin. Epub August 19, 2011.
82. Moffitt TE. The new look of behavioral genetics in developmental psychopathology: gene-environment interplay in antisocial behaviors. Psychol Bull. 2005;131(4):533-554.

83. Rutter M, Plomin R. Pathways from science findings to health benefits. Psychol Med. 2009;39(4):529-542.

84. Uher R. The implications of gene-environment interactions in depression: will cause inform cure? Mol Psychiatry. 2008;13(12):1070-1078.

85. Uher R. Genes, environment, and individual differences in responding to treatment for depression. Harv Rev Psychiatry. 2011;19(3): 109-124.

86. Collins F. Has the revolution arrived? Nature. 2010;464(7289): 674-675.

87. Lester KJ, Eley TC. Therapygenetics: Using genetic markers to predict response to psychological treatment for mood and anxiety disorders. Biol Mood Anxiety Disord. 2013;3(1):4.

88. Reif A, Richter J, Straube B, et al. MAOA and mechanisms of panic disorder revisited: from bench to molecular psychotherapy. Mol Psychiatry. 2014;19(1):122-128.

89. Cicchetti D, Rogosch FA. Gene $\times$ Environment interaction and resilience: effects of child maltreatment and serotonin, corticotropin releasing hormone, dopamine, and oxytocin genes. Dev Psychopathol. 2012;24(2):411-427.

90. Cicchetti D, Rogosch FA, Toth SL. The effects of child maltreatment and polymorphisms of the serotonin transporter and dopamine D4 receptor genes on infant attachment and intervention efficacy. Dev Psychopathol. 2011;23(2):357-372.

91. Munafò MR, Clark TG, Moore LR, Payne E, Walton R, Flint J. Genetic polymorphisms and personality in healthy adults: a systematic review and meta-analysis. Mol Psychiatry. 2003;8(5):471-484.

92. Bernet W, Vnencak-Jones CL, Farahany N, Montgomery SA. Bad nature, bad nurture, and testimony regarding MAOA and SLC6A4 genotyping at murder trials. J Forensic Sci. 2007;52(6):1362-1371.

93. Feresin E. Lighter Sentence for Murderer with "Bad Genes." London, UK: Nature Publishing Group; 2014. Available from: http://www. nature.com/news/2009/091030/full/news.2009.1050.html. Accessed May 28, 2014

94. Pioro M, Mykitiuk R, Finkler L, Nisker J. Understanding the use of "genetic predisposition" in canadian legal decisions. McGill J Law Heal. 2013;7(1):1-65.

95. Farahany NA, Coleman JE Jr. Genetics and responsibility: to know the criminal from the crime. Law Contemp Probl. 2006;69:115-164.

96. Baum ML. The monoamine oxidase A (MAOA) genetic predisposition to impulsive violence: is it relevant to criminal trials? Neuroethics. 2011;6(2):287-306.

97. Hung CF, Lung FW, Hung TH, et al. Monoamine oxidase A gene polymorphism and suicide: an association study and meta-analysis. J Affect Disord. 2012;136(3):643-649.

98. Caspi A, Houts RM, Belsky DW, et al. The p Factor: one general psychopathology factor in the structure of psychiatric disorders? Clin Psychol Sci. 2013;2(2):119-137.

99. van Ijzendoorn MH, Belsky J, Bakermans-Kranenburg MJ Serotonin transporter genotype 5HTTLPR as a marker of differential susceptibility? A meta-analysis of child and adolescent gene-byenvironment studies. Transl Psychiatry. 2012;2:e147.

100. Kinnally EL, Huang Y, Haverly R, et al. Parental care moderates the influence of MAOA-uVNTR genotype and childhood stressors on trait impulsivity and aggression in adult women. Psychiatr Genet. 2009;19(3):126-133.

101. Weder N, Yang BZ, Douglas-Palumberi H, et al. MAOA genotype, maltreatment, and aggressive behavior: the changing impact of genotype at varying levels of trauma. Biol Psychiatry. 2009;65(5): 417-424.

102. Gray NS, Snowden RJ, MacCulloch S, Phillips H, Taylor J, MacCulloch MJ. Relative efficacy of criminological, clinical, and personality measures of future risk of offending in mentally disordered offenders: a comparative study of HCR-20, PCL:SV, and OGRS. J Consult Clin Psychol. 2004;72(3):523-530. 
103. Hudson JL, Lester KJ, Lewis CM, et al. Predicting outcomes following cognitive behaviour therapy in child anxiety disorders: the influence of genetic, demographic and clinical information. J Child Psychol Psychiatry. 2013;54(10):1086-1094.

104. Doehrmann O, Ghosh SS, Polli FE, et al. Predicting treatment response in social anxiety disorder from functional magnetic resonance imaging. JAMA Psychiatry. 2013;70(1):87-97.

105. Lester KJ, Eley TC. Therapygenetics: Using genetic markers to predict response to psychological treatment for mood and anxiety disorders. Biol Mood Anxiety Disord. 2013;3(1):4.

106. Ebstein RP. The molecular genetic architecture of human personality: beyond self-report questionnaires. Mol Psychiatry. 2006;11(5): 427-445.

107. Nilsson KW, Wargelius H-L, Sjöberg RL, Leppert J, Oreland L. The MAO-A gene, platelet MAO-B activity and psychosocial environment in adolescent female alcohol-related problem behaviour. Drug Alcohol Depend. 2008;93(1-2):51-62.

108. Beach SR, Brody GH, Gunter TD, Packer H, Wernett P, Philibert RA. Child maltreatment moderates the association of MAOA with symptoms of depression and antisocial personality disorder. J Fam Psychol. 2010;24(1):12-20.
109. Derringer J, Krueger RF, Irons DE, Iacono WG. Harsh discipline, childhood sexual assault, and MAOA genotype: an investigation of main and interactive effects on diverse clinical externalizing outcomes. Behav Genet. 2010;40(5):639-648.

110. Edwards AC, Dodge KA, Latendresse SJ, et al. MAOA-uVNTR and early physical discipline interact to influence delinquent behavior. J Child Psychol Psychiatry. 2010;51(6):679-687.

111. McGrath LM, Mustanski B, Metzger A, et al. A latent modeling approach to genotype-phenotype relationships: maternal problem behavior clusters, prenatal smoking, and MAOA genotype. Arch Womens Ment Health. 2012;15(4):269-282.

112. Williams LM, Gatt JM, Kuan SA, et al. A polymorphism of the MAOA gene is associated with emotional brain markers and personality traits on an antisocial index. Neuropsychopharmacology. 2009;34(7):1797-1809.

\section{Publish your work in this journal}

Psychology Research and Behavior Management is an international, peerreviewed, open access journal focusing on the science of psychology and its application in behavior management to develop improved outcomes in the clinical, educational, sports and business arenas. Specific topics covered include: Neuroscience, memory \& decision making; Behavior

\section{Dovepress}

modification \& management; Clinical applications; Business \& sports performance management; Social and developmental studies; Animal studies. The manuscript management system is completely online and includes a quick and fair peer-review system. Visit http://www.dovepress. com/testimonials.php to read real quotes from published authors.

\footnotetext{
Submit your manuscript here: http://www.dovepress.com/psychology-research-and-behavior-management-journal
} 